\title{
SIMPLIFIED CRIMINAL ACCUSATIONS AND THE SUPPLEMENTING AND AMENDING THEREOF
}

In a prior article, the writer reached the conclusion that the formal charge should allege only so much matter as would ensure a fair trial in the ordinary normal case. The reasoning was this: The present system of criminal pleading is not flexible enough; it should be made more flexible by giving the courts power to compel the supplementing of the formal charge by bills of particulars, and to compel the amending of the formal charge when it does not correspond with the facts proved. Speed and celerity of punishment are desirable. If the indictment is made too brief, the accused has opportunity to secure postponements of the trial while he asks for bills of particulars and pleads surprise when unexpected evidence is presented by the prosecution. If the indictment is made too long, the accused will similarly delay the trial while he picks flaws and defects in the charge and pleads surprise when the allegations of the indictment are different from the facts established. Thus brevity and prolixity in the indictment may each give rise to delay. The opportunities for delay do not vary directly as the indictment is made more or less complex. They vary in gcometric ratio. Take any form of indictment as a standard. An indictment twice as complex will give, not twice the opportunity to delay on account of defects, but more than twice as many; and an indictment containing but half the matter will give opportunity to more than twice as many opportunitics for delay by asking for futrher information. What is necessary for a fair trial in the normal or average case should therefore be taken as the standard. If the standard be made less than the normal the delays for further information will increase more in number than the delays for defects will diminish. And if the standard be made more than the normal the delays for defects will increase more in number than the delays for further information will diminish. There is, however, one form

${ }^{2}$ Reform of Criminal Procedure, University of Pennsylvania Law Review, Vol. 61, p. 458 . 
of indictment for each separate offense which, when used, will reduce the combined causes of delay to a minimum.

This model indictment is to be part of a system of procedure which has the following features: The first pleading on the part of the state is the formal accusation, the contents of which we propose to discuss subsequently. This formal accusation may be supplemented at the request. of the accused when he shows that information not found therein is desirable in order that he may have a fair opportunity to present his defenses. Both the original and the supplemental accusations imay be freely amended when it appears that they do not state the transaction as it actually transpired. The defendant has the right to secure postponement of the trial when he shows that he is not prepared to meet the facts as actually proved.

A study of the laws governing criminal pleading and the cases interpreting such rules as found in the statute books and reports of the various American jurisdictions does not assist the inquirer to any great extent in the task of determining what averments should be found in the model indictment under this system of procedure. The reason is this: Most of the states have found that the common law forms were too cumbersome and that they contained too much matter. They have, therefore, in varying degrees, simplified the indictment. They have not, however, given the accused the right to compel the prosecution to give further information when desirable. Since the accused does not have this right, the formal accusation has not been simplified to an extent which would be unfair to the accused in any considerable number of cases.

It is thercfore impossible to determine from a study of these statutes just what is the practical limit of brevity, or the extent to which the indictment used in this model code should be simplified. To this extent only is an investigation of American statutes valuable: it is certain that none of the forms given mark the limit of brevity. No serious objection on the grounds of injustice to the accused has ever been raised to the forms in use, and it is selfevident that, if such forms are sufficient to ensure a fair trial where the accused has no right to supplemental information, they are sufficient where he has such right. Certain states do permit the use of bills of particulars, but it appears that the forms in such states are no more brief than are the forms in the states which deny that right. 
There are, however, certain codes of procedure in force at present which embody these rights to frecly suppiement, and to freely amend. The Massachusetts Corlet is drawn on those lines. The Code which is in force in Canada' and New Zealand' is based upon the same theories and the Code of Criminal Procedure in force in Indias is a perfect embodiment of the theories. A study of the forms prescribed by these codes ought to aid in the determination of what the formal accusation should contain, and from these codes the following rules have been deduced.

The formal accusation or the charge, as it shall be termed hereafter, should state the offense with which the accused is charged. By this is meant that it should contain sufficient matter to identify the offense charged as distinguished from the particular transaction which constitutes the offense. Thus, the charge must show whether the accused is being prosecuted for murder, robbery, larceny or some other offense. This rule is found in every system of procedure. It is the irrelucible minimum. How then should the cinarge show what offense is intended? What averments are necessary? There are three ways in which the offense can be alleged: (1) by giving the name of the offense, if either the common law or statute has prescribed a distinctive name; (2) by citing the statute and section or subsection thereof alleged to have been violated, and (3) by stating so much of the definition of the offense as is necessary to show the offense intended to be charged.

In some fifteen or more American juristictions, the forms prescribed by the coles do contain a statement of the name of the offense, if it have one. It seems to be quite generally held under the other provisions of the coles in these jurisdictions that the insertion of the name is a formal matter. Its omission will be excused." Or if it appears that the facts, which must also be alleged, do not constitute the offense named, the name will be re-

\footnotetext{
2 Massachusetts Revised Laws, 1902; Chap. 218.

Criminal Corte. 55-56 V., Chap. 29; in Chap. 146, Revised Statutes of Canada, 1906, Part XIX.

The Crimes Act, 1908. Part $X$ in New Zealand Consolidated Statutes, 1908, No. 32, 386 ef seg. This colde and the Canadian cole are identical.

- Code of Criminal Procedure, 1898. Chap. XIX in Unrepealed General Acts, I898, Act X, Chap. XIX.

- State v. Baldy, 17 lowa 39 (1864).
} 
jected as surplusage. These forms also require a statement of the facts constituting the particular transaction and these facts must also be sufficiently full to identify the offense. The requirement for the statement of the name of the offense only complicates the indictment in these jurisdictions, and it was too complex at common law.

The Massachusetts Revised Laws provide that the insertion of the name of the offense when charging some ten offenses, shall be a sufficient statement of the offense. Why this limit was set is not clear. The Penal Codes of New Zealand and Canada do not give names to the offenses defined and their Procedural codes do not-require the insertion of any names. The Criminal Procedure Code of India' requires that the name of the offense be stated in the charge.

The second way in which the charge may specify the offense for which the prosecution is brought is by a reference to the statute alleged to have been violated. Neither at common law nor under any statute in the United States is any reference to the particular statute creating or defining the offense required in an indictment; and further, if any such reference is found therein, it is rejected as surplusage. It is not considered in determining the sufficiency of the indictment.

The Canadian Code'" provides that

"a count may refer to any section or subsection of any statute creating the offense charged therein, and in estimating the sufficiency of such count the court shall have regard to such reference."

The Indian Cocle"t requires that

"the law and section of the law against which the offense is said to have been committed shall be mentioned in the charge."

The individuals who have formulated other model codes of procedure have invariably seen fit to require the insertion of the

T State v. Howard, 66 Minn. 309 (1896); State v. Davis, 41 Iowa 311 (1875); contra, Pcople v. Quartarabo, 133 N. Y. Supp. 985 (1902).

Chap. 218, 338.

- Chap. XIX, \&22I (2).

$10 \$ 873$, subsec. a.

II 8221, subsec. 4. 
statute alleged to have been violated. The code of E. D. Lewist and the Draft Code prepared by H. L. Stephen ${ }^{13}$ for England do so.

It cannot be doubted that the citation of the particular statute, the violation of which is charged, would be of great assistance to the accused. He or his counsel must always look up the statute in order to prepare his defense as to the law. Under the present procedure he must study the allegations of the indictment and then search among numcrous statutes to find what offense contains the elements which are averred in the charge. A direct reference to the statute would make unnecessary such search.

The charge may specify the offense committed in a third way; namely, by alleging so much of the definition of the offense as is necessary to show what offense is intended. This is a modification of the common law rule which requires that the indictment shall state all the essential elements of the offense. This common law rule is in effect in every American jurisdiction, but no good reason can be shown for its existence in the present rigorous form. There is no reason why an indictment which contains sufficient matter to show what offense is intended should not be sufficient to chargesuch offense. The law says that nothing shall be taken by intendment, when averring the essential elements of the offense. But why should not the elements of the offense be stated by intendment if the indictment shows what is intended? There might be some reason for requiring the indictment to state each and every element of the offense, if there were a corresponding rule which said that the indictment was invalid which stated matters not essential to a description of the offense. Then the accused would be entitled to an acquittal if he proved that any averment of the charge did not correspond with the actual facts. There is no such ruie. The accused is not acquitted on a charge of "wilfully" doing an act when he proves that he did not do the act wilfully, if the statute creating the offense does not make "wilfullness" an essential clement of the offense. The accused must now search through uncssential averments of the indictment to discover what is intended to be es-

12 See A Draft Code of Criminal Law and Procedure, appendix, Form A. A. 1 and \$287.

"See Report of Committce E, in Journal of Criminal Lay and Criminology. Vol. 1, p. 589 (1910). 
sential. But such indictment is valid, although it may be misleading in that it aileges too much matter. An indictment therefore shouid not be held invalid unless it alieges so little matter as to be misleading. The real quarrel here is with the interpretation which the courts have put upon the use of the term "essential elements of the offense." Different courts have given the term different meanings, but none of them have said what should be said when using the term in connection with indictments, namely, that the essential elements of the offense are those which must be charged. in order to give the accused fair notice of the offense to be charged. If fairness to the accused be made the test of essentiality, there can be no objection to the retention of the rule that the indictment must state the essential elements of the offense. This change in the definition of the term "essential elements" is not unprecedented. Premeditated intention is an essential element of murder in the first degree in the sense that it must be proved on the trial, but the majority of jurisdictions hold that it need not be alleged in the indictment." In spite of Mr. Bishop's strenuous objections, no one has ever contended that the omission of this element has ever deprived a person accused of murder of a fair trial on the merits of the case. If an element essential to be proved may be omitted in an indictment for the most scrious offense of all, why may not similar elements be onitted in indiciments for less serious offenses?

No American Code has any provision which permits generally the omission of any clement of the offense which must be proved by the prosecution. The Canadian Code" permits the amendment of any count in which there appears

"an omission to state or a defective statement of anything requisite to constitute the offense" provided that "the accused has not been misled or prejudiced in his defence by such error or omission."

This, in effect, makes valid an indictment which omits essential elements, but the burcien is on the state to show that such omission has not prejudiced the accused. The Indian Code' merely requires that

"Sce Bishop, New Criminal Procedure, Vol. II, \$584.

It 8889, subsec. 2.

16 \{221. 
"if the law which creates the offense does not give it any specific name, so much of the definition of the offense must be stated as to give the accused notice of the matter with which he is charged."

Any one of these three methods of identifying the offense would be sufficient to enable the accused to prepare his defence as to the law. The charge which identifies the offense in one or more of these ways, would ensure to the accused a fair trial in that respect. But the accused should also be given such information in the charge as will in the ordinary case enable him to prepare his defense on the facts. The charge should :dentify the particular transaction constituting the offense and distinguish it from other transactions of like nature. The allegations which identify the nature of the offense and the allegations which identify the specific transaction are, in the nature of things, inextricably mixed in any charge. The same averments serve both functions. The question now to be considered is, how much particularity should be added in a charge which does charge that a certain offense has been com. mitted to show what transaction is the basis of the charge. For example: The charge alleges that the accused committed robbery; what more should the charge state to show what robbery is intended?

It is exceedingly difficult, if not impossible, to frame general rules, governing all classes of offenses, as to what should be stated in order to identify the transaction. One must take up each offense separately and decide what distinguishing features should be emphasized in order to differentiate the particular transaction for which the accused is to be put on trial from others of the same type with which he or other persons may have been connected. Without considering each offense separately, although this ought to be done when a complete code is drafted, the following general observations are submitted as controlling.

The time and place of the commission of the offense should be alleged. Each offense, using the term now in the sense of the transaction constituting an offense, occurs at a time and place which absolutely distinguishes it from other offenses. This should be a general rule governing all classes of offenses and is in fact the only general rule so applicable. All other rules will necessarily apply only in certain classes of cases and some rules such as these are hereafter submitted. If the offense is. directed against any 
person, the name of the person shou'd be stated or he should be described in a manner calculated to reasonably inform the accused which person is intended. If tie offense is directed against property, the property should be described in a reasonable manner and the name of the owner should be added if the property is of such character that the description without the name of the owner does not give the accused fair notice. If, however, the property be such that the description differentiates if from the mass of property of the same character, the name of the owner might well be omitted. If the offense be committed in respect to some certain thing, not property, that thing should be specified in a reasonably accurate manner. If the offense be directed toward no particular person, property or thing, then the charge should specify the circumstances of the particular transaction in a manner which would distinguish it from similar transactions.

In but one American jurisdiction do we find a general statute which legalizes short forms such as the scheme outlined above permits. This state is Massachusetts, a statute' of which provides that

"an indictment shall not be quashed or be considered defective or insufficient if it be sufficient to enable the defendant to understand the charge and to prepare his defense; nor shall it be considered defective or insufficient for lack of any descrip. tion which might be obtained by requiring a bill of particulars."

This section taken in connection with the other sections of the statute practically embodies the ideas here set forth.

The Canadian Code " reads:

"Every count of an indictment shall contain so much detail of the circumstances of the alleged offense as is sufficient to give the accused reasonable information as to the act or omission to be proved against him and to identify the transaction referred to; provided that the absence or insufficiency of such details shall not vitiate the count."

(Note the proviso; its effect will be discussed subsequently.)

The Indian Code's reads that:

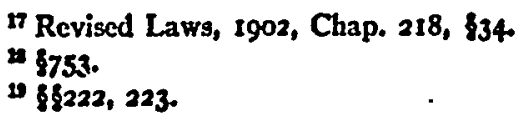


"the charge shall contain such particulars as to the time and place of the alleged offense, and the person (if any) against whom, or the thing (if any) in respect of which it was committed as are reasonably sufficient to give the accused notice of the matter with which he is charged.

"When the nature of the case is such that the particulars mentioned in $\$ \$ 221$ and 222 do not give the accused sufficient notice of the matter with which he is charged, the charge shall also contain such particulars of the manner in which the alleged offense was committed as will be sufficient for that purpose."

The general rules which we have proposed for determining the sufficiency of the averments which are to enable the accused to prepare his defense differ from the rules of the Canadian and Indian Codes in this respect. These codes say that the charge shall contain so much matter as is necessary to afford the accused reasonable information in each and every case; $i$. e., each case is to stand on its own merits, and if it were not for saving sections found elsewhere in the code the validity of each charge would depend upon the particular circumstances of each particular case. The rules here proposed make the average case the standard and do not let each case stand or fall on its own merits.

The remedial sections of the Canadian and the Indian Codes show how completely each case is intended to stand on its own merits. The Indian Codeso reads:

"No error in stating either the offense or the particulars required to be stated in the charge, and no omission to statethe offense or those particulars shall be regarded at any stageof the case as material unless the accused was in fact misled by such error or omission, and it has occasioned a failure of justice."

\section{The Canadian Code' provides:}

"That the absence or insufficiency of such details of the transaction shall not vitiate the count, and that the court shall amend an omission to state or a defective statenient of anything requisite to constitute the offense-if the matter omitted is proved by the evidence."

These two codes differ in that under the Canadian Code an indictment which does not identify the offense may be quashed if objec-

$20 \$ 225$.

2853. 
tion be taken before trial, 22 while under the Indian Code the formal charge can never be quashed entirely, but the court will amend it in all respectsis if it does not conform to the rules.

Therefore it would seem that under the Indian Code an accused person may be put on trial without any formal charge to identify either the offense or the transaction constituting the offense if as a matter of fact he is or should be prepared to meet the case to be proved against him, having obtained the requisite information at the preliminary hearings. Under the Canadian Code, the accused cannot be put to trial against his objection on a charge which does not identify the offense, although he may be tried on a charge which does not specify the transaction. Thus:20

"Every count of an indictment shall contain and shall be sufficient if it contains in substance, a stalentent that the accused has committed some indictable offense therein specified."

This setting of a low minimum requirement, which in the one case is really nothing, and in the other is the offense, has these advantages. It prevents delays and appeals based on technical rules of pleading, since all motions and appeals must then be based on the single proposition, whether the accused will be or was fairly tried or not. It also enables the court and the prosecuting officers to work out by practice a form of charge for each particular offense which will give rise to the least delay in the trial of the list of cases. The forms that would be used under such minimum requirements would be, and it is submitted, are, in Canada, New Zealand, and India, those forms which in the long run cause the fewest number of postponements of trials.

Then why, if, under a system of pleading setting lower requirements for the charge, fair trials and speedy punishment are secured, should the higher requirements, that the charge shall identify both the offense and the transaction constituting such offense, be set? The reason is: Every state in the United States, and the Federal Government itself, has a constitution which sets

2. v. Weir, L. R. 9 Q. B. 253 (1900).

2 8226. "When any person is committed for trial without a charge, or with an imperfect or erroneous charge, the court. ......... may frame a charge or add to or otherwise alter the charge, as the case may be, having regard to the rules contained in this code as to the form of charges."

25852. 
limitations upon any system of criminal procedure. The usual provision which, with variations in terminology, is found in every constitution, is that the accused person shall have the right "to demand the nature and cause of the accusation against him." This article will close with a full discussion of the effect of this provision and therefore only the conclusions of the writer will be presented here. They are as follows.

The right to demand the nature and cause would be valueless unless it also included the obligation on the part of the state to furnish information as to the nature and cause of the accusation upon such demand. This right is given to the accused and irrespective of whether the nature of the case requires for a fair trial that he receive that information in writing in the particular case. He must be given specific information even though he knows all the facts and circumstances necessary to assure him a fair trial. The right to be informed of the nature of the accusation means that the charge must specify some offense. The decisions state that a formal charge specifying the offense is an absolute prerequisite to the jurisdiction of any court of record. It therefore cannot be waived by the accused. He may object at any stage of the proccedings to the jurisdiction of the court. Just why a statute would not be constitutional which would provide that the court should have jurisdiction where the accused was as a matter of fact informed of the nature and cause of the accusation without a formal written charge, is not clear, but that such a statute would not be constitutional seems firmly established by the cases. A code which would question that principle would give rise to much litigation on appeal. It would therefore defeat its own purpose, namely to avoid delay in punishment. The constitutions, thercfore, set one absolute requirement; namely, that the charge must contain sufficient matter to identify the offense.

The right to be informed of the cause of the accusation means that the charge must specify the transaction which constitutes the offense. This right may be waived by the accused, but if he does not demand information as to the specific transaction, he must be given it, regardless of whether he would or would not be tried fairly without it. Since the accused has this right he will, in the vast majority of cases, insist upon it, either because he conceives the information to be necessary for a fair trial, or because he hopes 
thereby to embarrass the prosecution. It is, therefore, advisable that the charge should, when first drawn, identify the transaction. This will obviate the otherwise frequent delays which would occur when the accused did, as he most frequently would, demand that the information be given him.

Another constitutional provision compels the same minimum requirements. In many states it is provided that the trial shall be by indictment. The practical effect, though perhaps not the theoretical effect, of this provision is that, before a person can be put on trial, a grand jury must hear the evidence against him and decide whether or not there is probable cause for prosecuting him for some particular offense. The indictment as passed upon by the grand jury should aver sufficient matter to show for what offense the grand jury found probable cause to send the case to the petit jury. To permit trial upon an indictment which did not specify the offense would not be trial by indictment. Whether the constitutions require that the indictment should identify the transaction as well as the offense is questionable. It would seem that they do not, but no cases have flatly decided that it would or would not be trial by indictment to put the accused on trial on an indictment which merely charged the commission of a certain offense without stating matter to differentiate in some manner the facts constituting the offense from like facts. An analysis of the cases would seem to prove that such indictment would be valid if it be made part of a system of procedure which would also give the accused the right to obtain the particulars on demand.

Thus far we have discussed what the formal charge should contain. The next question is, what should be done if the charge does not conform to these minimum requirements? The conclusions of the writer on this question are as follows:

If the charge does not sufficiently identify the offense (as distinguished from the transaction) the charge should be set aside or quashed no matter at what stage in the case the defect is pointed out. The whole case must then be begun anew. This rule may not be desirable and undoubtedly will cause many delays and retrials in cases where the offense was not indicated but substantial justice was more or less done in the trial. The constitutional provisions previously discussed however render such a rule imperative. 
If the charge does not contain sufficient averments to identify the transaction and so enable the accused to prepare his defense as to the facts, the accused should have the right to compel the prosecution to furnish him with such information as is desirable for that purpose. This may be done by giving him the right to a bill of particulars. Under the proposed code the bill of particular will differ in certain respects from that known to the common law. At common law the bill of particulars is given to the accused as a matter of grace on the part of the trial court to supplement the information contained in the indictment. It is no part of the pleadings and so no legal objection can be raised as to its sufficiency. The appellate courts will not review the action of the trial court in granting or refusing the bill, except in cases of gross abuse of the discretion. The reason back of these common law rules was that the indictment was. considered as fully identifying both the offense and the transaction constituting the offense. Theoretically the accused never needed any information not contained in the indictment for a fair trial."

Under the proposed code, the accused is given an absolute right to a bill of particulars, amending and supplementing the charge, to the extent that the bill should satisfy his constitutional right to demand the nature and cause of the accusation against him. He may also be given information not required by the constitution, but his right thereto will be discretionary with the court and shall be dependent upon the circumstances of the case. The bill of particulars will be made part of the record and will supplement and amend the formal charge first presented. Objection can be taken to its sufficiency on the ground that the transaction set out therein does not cunstitute the offense charged as a matter of law and, when that is so, the entire charge may be quashed, if the prosecuting officer is unable or unwilling to file a supplemental bill which will cure the defects of the previous bill.

Thus there may be two or more separate documents, one of which identifies the offense and the other identifies the transaction, which together on the record state the entire charge against the accused. The constitutional rights of the accused to be informed of the nature and cause of the accusation against him are thus

"Sherrick v. State, 167 Ind. 345 (1906). 
preserved. It would seem that the accused may waive his right to be informed of the transaction and he should be held to have waived that right where he fails to ask for a bill of particulars at the proper time. Under this code, the proceedings would be delayed in cases where the charge failed to identify the transaction, the extent of the delay being dependent upon the circumstances of each particular case, since it would be only so long as would be necessary for the accused to obtain his witnesses to meet those facts which were for the first time brought to his attention. Thus, if the preliminary hearings should disclose the entire case against the accused, and a formal charge should be drawn which identifies the offense and not the transaction, and the accused should later insist upon a bill of particulars to satisfy his constitutional rights, in such a case no delay would occur in the putting of the accused on trial, since he would be in actual receipt of all the information against him and could be fairly tried without any delay. If, on the other hand, the bill of particulars gave the accused his first notice of the transaction to be proved against him, he would be entitled to such postponement as would be necessary for a fair trial. In no case would the entire proceedings be dismissed nor would the prosecution be brought anew when the first formal charge failed to identify the transaction, as happens under the present law.

As has been noticed, one section" of the Canadian Code provides that the absence of sufficient details to identify the transacton referred to shall not vitiate any count. Since these details may be necessary for a fair trial, other sections ${ }^{27}$ provide that

"the court may, if satisfied that it is necessary for a fair trial, order that the prosecutor shall furnish a particular,-

(a) of what is relied on in support of any charge of perjury, the making oi a false oath or of a false statement, fabricating evidence, or subornation, or procuring the commission of any such offenses;

(b) or of any false pretences or any fraud charged;

(c) of any attempt or conspiracy by fraudulent means;

(d) stating what passage in any book, pamphlet, newspaper or other printing or writing, are relied on in suport of a

218853.

I7 8\$859, 860. 
charge of selling or exhibiting an obscene book, pamphlet. neswpaper, printing or writing:

(e) further describing any document or words the subject of a charge;

(f) further describing the means by which any offensewas committed;

(g) further describing any person, place or thing referred to in any indictment.

(S. 860) "When any particular as aforesaid is delivered . . . it shall be cntered in the record, and the trial proceed in all respect as if the indictment had been amended in conformity with such particulars."

Thus, in Canada, the charge may consist of an indictment and a bill of particulars amending and supplementing the indictment.

It is also provided ${ }^{2}$ that:

"in determining whether a particular is required or not - . . the court may have regard to the depositions"

which are not part of the record, but to which the accused had ac-. cess. This means that the accused has no right to a bill of particulars unless justice and fairness require it. Our constitutions require that he be given such a right regardless of fairness to him.

The Indian Code accomplishes the same result without the use of a bill of particulars. A certain section" reads that:

"Any court may alter or add to any charge at any time before judgment is pronounced,"

and subsequent sections give the court power to proceed immedi-. ately with the trial or to postpone the case as the interests of justice require.

In but one state of the United States is the bill of particulars used to accomplish the purposes which it accomplishes under the model cocle: namely, to cure lack of sufficient identification of the transaction in the indictment. One section ${ }^{30}$.of the Massachusetts statute provides that

"an indictment shall not be considered defective or insufficient for lack of any description or information which

\$860, subsec. 2.

$\$ 227$ (1).

0834 
might be obtained by requiring a bill of particulars as provided in section thirty-nine"

which section reads in part as follows:

"The court may . . . . order the prosecution to file a statement of such particulars as may be necessary to give the defendant and the court reasonable knowledge of the nature and grounds of the crime charged; and if it has final jurisdiction of the crime, shall so order at the request of the accused if the charge would not be otherwise fully, plainly, substantially and formally set out."

- The cases treat the bill of particulars given under this section as part of the formal charge, and the indictment and the bill of particulars together are valid if they contain sufficient matter to satisfy the constitutional requirements."n

The right of the prosecution to freely amend and supplement the charge will not, under the model code, cease when the accused is put on trial. If a variance appears between the evirjence offered and those allegations of the indictment or the bill of particulars which serve to identify the transaction, the indictment and the bill of particulars may be amended to conform to the proof. 'And such amendment will be made regardless of whether the accused is thereby prejudiced in his defense or not. He will, however, be entitled to a postponement of the case if he can show that he is surprised by the evidence offered and is therefore unable to meet it. In that it permits amendment under all circumstances, the proposed code would differ from the present statutes permitting amendment of the indictment in case of variance. The majority of statutes are modeled after the English statute"s and the draftsmen of these various statutes permitting amendment of variances have but rarely gone the full ength of permitting amendment of all variances between proof and those allegations of the charge which identify the transaction. Instead of providing that all such variances shall be amendable they have enumerated certain allegations which do identify the transaction, as distinguished from the offense, and provided that these variances shall be amendable. Thus the English statute reads:

" Comm. v. Kelly, 184 Mass. 320 (1903); Comm. v. Sinclair, 195 Mass. 100 (1907).

\& 14 \& 15 Vict., Chap. 100, \&1 (1851). 
"Whenever on the trial of any indictment for any felony or misdemeanor there shall appear to be any variance between the statement and the evidence offered in proof thereof;

"In the name of any county, division, city, borough, town, corporate, parish, township or place mentioned or described in any such statement;

"Or in the name or description of any person or persons or body politic or corporate, therein stated or alleged to be the owner or owners of any property, real or personal, which shall form the subject of any offense charged therein;

"Or in the name or description of any person or persons or body politic or corporate, therein stated or alleged to be injured or damaged or intended to be injured or damaged by the commission of such offense;

"Or in the christian name or surname, or both christian name and surname, or other description whatsoever, of any person or persons whomsoever therein named or described;

"Or in the name or description of any matter or thing whatsoever thercin named or described, or in the ownership of any property named or described therein;

"It shall and may be lawful for the court before which the trial shall be had, if it shall consider such variance not material to the merits of the case, and that the defendant cannot be prejudiced thereby in his defense upon such merits, to order such indictment to be amended according to the proofs, by some officer of the court or other person."

This is a fairly complete list of those allegations which identify the transaction, but some were omitted. In Reg. v. Smith," it was held that the section did not authorize amendment where, in an indictment for false pretence, it was alleged that the defendant had pretended that he had served a justice notice on a certain person, and the proof showed that he had said that he had served the notice on the landlady of that person.

The statutes in effect in the various jurisdictions vary in the number and character of the allegations of details which may be amended. Only three American statutes go the full length, under any interpretation thereof, of making possible the amendment of all those allegations which serve merely to identify the transaction. The Michigan" and Wisconsin"statutes permit amendment:

26 Cox. 31 (1852); contra, but doubtful, Rex y. Byers, 1907, 71 J. P. 205: Rex v. Jackson, 4 S. R. 732 (N. S. Wales, 1904).

H Act 77, 1855, p. 141 in Michigan Compiled Laws, $1897,811.922$

"Wisconsin Statutes, \$4703. 
"in all cases wherever the variance between the facts alleged in the indictment and those proved by the evidence are not material to the merits of the case."

The term "material to the merits of the case" is indefinite, but it would seem that only those allegations which identify the offense are material. The South Carolina statute does exactly what the proposed statute will do in a section" which permits the amendment of all variances "provided such amendment does not change the nature of the offense charged." The nature of the offense charged is shown by the averments which identify the offense, and so all other allegations are amendable.

The Canadian Code" permits the amendment of variances in all cases where the prejudice created thereby may be removed by postponement; and the Indian Code"says that "any court may alter or add to any charge at any time before judgment is pronounced."

All of the statutes provide for postponement of the trial "to be had before the same or another jury," in cases where prejudice and surprise arise under the newly disclosed state of facts, and a similar right should be given the accused under the proposed code.

The proposed reforms do not involve any changes in the fundamental principles which now govern the procedure by formal accusation. When the rules here advocated are applied to procedure by information, the sole test of the sufficiency of such information will be, does it fairly apprise the accused of the nature and cause of the accusation against him? If an information does not fairly inform the accused of the cause of the accusation, which may happen when it fails to set out the details of the transaction or when such details are incorrectly set out, the information may be supplemented and amended at once, only so much delay in the trial resulting as is necessary to insure a fair trial to the defendant. The necessity for recommencing the entire prosecution will be done away with.

Nor does the reform herein advocated involve any change in the principles governing procedure by indictment. The grand jury will still hear evidence as to the transaction constituting the

"Criminal Code of South Carolina, 885.

" 8889.

\$\$227. 
offense and in all probability it will be the same evidence which will later be presented to the petit jury. There is no likelihood that the prosecuting officer will ever prove to the grand jury that A murdered $B$ at a certain time and place and by certain means and then comebefore the petit jury and prove that $A$ murdered $C$ at another time and place and by different means.

With the usual provisions in regard to the indorsement of the witnesses' names on the indictment, any right which the accused may have to be tried for the same transaction for which he was indicted is fully protected. The accused will, however, be deprived of the use of the indictment when he attempts to show that there were two distinct transactions. The presumption will be that the grand jury heard evidence as to the transaction proved at the trial and based their indictment thereon, regardless of whether the indictment contains any allegations to show that such is the case, or whether the allegations therein stated would seem to show that the contrary was so. At common law it was said that the indictment was invailid which failed to allege the particulars of the transaction with such particularity that there could be no doubt as to the transaction intended to be charged; and further, if the indictment was more particular than the rules required, it was conccived that the grand jury could not have intended a transaction identical, in all respects but one, with the transaction set forth. Thus an indictment which charged the larceny of a watch from $A$. $B$. was valid and under it the defendant could be convicted of stealing a gold watch from $A$. B. and the court would not hear evidence that A. B. had had a silver watch stolen at the same time and that the grand jury had intended to indict the accused for stealing the silver watch. The presumption was that the 'grand jury intended to indict for the theft proved. If, however, the grand jury charged that the accused stole a silver watch, and it was proved that he had stolen a gold watch, which was the only watch that A. B. had ever possessed, the court refused to presume that the grand jury intended to charge the theft of the gold watch, and took the view that the grand jury meant exactly what was averred in the indictment. This view has been changed by the

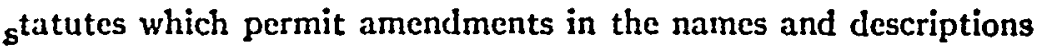
of persons, places and things, when the facts proved do not correspond with the facts alleged. The presumption that the state of 
facts proved is the state of facts intended to be charged by the grand jury has thus been extended to cases were the indictment would seem to show otherwise. Under the proposed code, as under any of the statutes permitting amendment of the indictment in cases of variance, the accused may in the very exceptional case be deprived entirely of the use of the indictment as evidence of what transaction the grand jury intended to indict him for. The opportunity for indicting a man for one transaction and proving another at the trial could arise only when the accused had committed numerous offenses of like nature and even he would be protected in such a case by the necessity of calling the same witnesses before both the grand and the petit juries.

The legislative bodies of the jurisdictions whose statutes have for the most part been taken as exampies are not restrained by any constitutional provisions from setting any forn of criminal accusation which is desirable. Each and every legislative body in the United States is restrained to a certain extent by the constitutions. Therefore it might well be that the procedure permissible in Canada, New Zealand and India, could never be put into operation in the Federal or other jurislictions of the United States. It is therefore necessary to determine from a study of the cases, just what limits are set to the powers of the various legislatures to prescribe the rules which shall govern the formal accusations.

It is impossible to reconcile all the cases which deal with the constitutionality of statutes which change the common law rules governing the allegations which should be found in an indictment. It is even impossible to reconcile on theory the cases in any one of the majority of jurisdictions. If we study the cases in the courts of any juriscliction where a considerable number of cases have arisen dealing with the constitutional question, we find that the court has enunciated a theory in one case which it never noticed in another case, or has said that a certain principle was controlling, which principle was never controlling at common law. Take the United States Supreme Court. In ex parte Bain, ${ }^{29}$ the court said that the provision of the United States constitution requiring procedure by indictment in certain cases, prohibited any changing of the body of any indictment. In this case the change was the striking out

* I21 U. S. I (1887). 
of an averment which was clearly surplusage; and under all the common law authorities this decision would seem to be wrong. But the theory of the court seemed to be that a bill found by the grand jury is not a constitutional indictment unless it distinctly shows on what transaction they based their finding. The indictment in the case alleged that the accused did certain acts with intent to deceive $A$ and $B$ and $C$ and $D$ and $E$ and others. The intent to deceive A was neither criminal nor material; so the trial court struck it out. The Supreme Court said that the indictment was unconstitutional on the ground that more than one of the grand jurors might have been satisfied that the act was done with intent to deceive $A$, but not convinced as to the intent to deceive the others, and so the accused might be tried for what the grand jury did not. determine and such trial would not be trial by indictment. Thecourt never considered whether, if the grand jury had originally found the indictment as it was when amended, they might not havebased their finding on an intend to defraud $B$ and the accused be tried for an intent to defraud $C$ and clearly under their first holding the latter case would not be trial by indictment; but when this. question was clearly presented to them in Rosen v. U. S., 10 in which case the indictment was for the mailing of obscene matter to the extent of twelve pages, and the accused insisted that the indictment. should show what particular pages were found to be obscene by the grand jury, the court said "that he was not entitled to know what passed in the conferences of grand jurors." The dissenting judges adopted the view of the accused, but the case was unanimously affirmed in Price v. U. S.42 Thus a certain principle was enunciated as prohibiting amendments to indictments, which was. repudiated when considering the sufficiency of indictments.

Similar inconsistencies may be found in the decisions of almost every state in the Union, and the court which does most consistently follow the rules which other courts pretend to follow has become the "awful example." The reference is to Texas. It would seem as though the only uniform test of constitutionality. should be and is "Was the accused fairly informed of the charge that he was to meet"? And the decision of this will rest largely on the facts of each individual case. This view is being frankly

\footnotetext{
4 161 U. S. 29 (1895).

a 165 U. S. 311 (1896).
} 
recognized and applied. Recent cases show less regard for technicalities, for rules said to be applicable in all cases. Take a very late case in the United States Supreme Court."2 Day, J., says:

"It is elementary that an indictment, in order to be good under the Federal Constitution and laws, shall advise the accused of the nature and cause of the accusation and prepare him for his trial and that, after judgment, he may bea ble to plead the record and judgment in bar of further prosecution for the same offense."

\section{And later on, he says:}

.As to the objection that the charge was so indefinite that the accused could not plead the record and conviction in bar of another prosecution, it is sufficient to say that in such cases it is the right of the accused to resort to parol testimony to show the subject matter of the former conviction and such practice is not infrequently necessary."us

Thus the second of the two standards first enunciated is repudiated in the same opinion and later on the court says:

"In the absence of a demand for a bill of particulars, we think this description (given in the indictment) sufficiently advised the accused of the nature and cause of the accusation against him."

The inference from these words is that the test of the sufficiency of the information given varies with each particular case and may be dependent upon information actually had by the accused, but not fourd in the charge.

This case is fairly illustrative of the more liberal attitude of the courts of all jurisdictions. Fairness to the accused is coming to be almost the sole test, and it would seem as though any reform in procedure will be held constitutional which insures to the accused full opportunity to secure all the information requisite to a fair trial.

The remainder of this article will be devoted to showing examples both at common law and under various statutes of applications of the various proposals previously set forth. There will

a Bartell v. U. S., 227 U. S. 427 (r913).

a Citing U. S. v. Claflin, 13 Blatchf. 178 (U. S., 1875): Dunbar v. U. S., 156 U. S. 185 (1895); Trubbs v. U. S., 105 Fed. Rep. 59 (1900). 
be no consistent attempt to discuss the numerous cases which have been decided on theories other than those here enunciated. Such a discussion would fill a la: ge volume. Therefore, with but incidental notice of the cases decided contra, the cases which support the theories of this paper will be discussed.

Before entering upon a discussion of the cases, the following premises are submitted for consideration. First: The constitutions require no greater particularity than did the common law. Any form of averment which was sufficient at common law is suffcient under the constitutions of the several jurisdictions. Numerous cases might be cited to show that the provisions of the constitutions require conmon law exactness in criminal procedure." And if common law sufficiency is required by the constitutions, common law sufficiency is all that is required. If, therefore, it is possible to show that in certain classes of cases, certain forms of allegation were sufficient, that is some cvidence that the same forms should be sufficient under the constitutions in other classes of cases. Another premise is that any form of averment which imparts to the accused as much really important information as did the common law forms, is also constitutional. This premise is not so firmly established as the other, but cases supporting it will be cited subsequently.

Let us apply these principles to the rules herein set forth. The first proposition was to indicate the offense, as distinguished from the transaction constituting the offense, by giving the name of the offense, or by referring to the statute violated, or by stating so much of the definition of the offense as is necessary to show what offense is intended. First, is the identification of the offense, by the name thereof, constitutional?

At common law there are four offenses, in charging which it is sufficient to use simply the name of the offense. These of-

4 English v. State, 3 I Fed. Rep. 340 (1893); Hewitt v. State, 25 Tex. Cr. Rep. 722 (1860); Mott v. State, 29 Ark. 147 (1874). These are a few of the more extreme cases.

13 See Archbold, Crim. Pr. \& Pl., 24 Ed., p. 1224. 1831).

11 Rex v. Maso, 2 T. R. $5^{81}$ (1788); Conm. v. Davis, 11 Pick. 432 (Mass.,

4 Rex. v. Uriyn, 2 Sand. (Wm. Ed.) 308, in notes; See Comm. v. McNarmara, 116 Mass. 390 (1874). 
fenses are affray," barratry," being a common scold," and being a common night walker." In these cases, averring the legal effect. of acts is held to be a sufficient statement of the acts constituting the offense. These cases show that the principle that the function .of the indictment is to state facts, not law, was not universally applicable, even at common law. The necessity for the use of certain technical words in indictments for certain offenses also shows that the rule is not universal "that a pleading need only -state facts, not law." "Whether an act amounts to a felony and was therefore "feloniously" done is a pure conclusion of law, but the indictment was bad which did not so characterize the doing of the act.so What the words "murder," "ravish," and "feloniously take and carry away" mean in indictments for murder," rape,"s and larceny, s2 respectively, is a pure conclusion of law from facts not alleged, and yet these words are sufficient to convey their legal meaning and must be used. In another class of cases the same manner of stating offenses is held sufficient. In charging burglary, the intent may be alleged in one of two ways. It is sufficient to allege that the accused broke and entered "with intent to commit. larcery therein," "or all the elements of the intended larceny must be fully disclosed." Thus the use of the term "larceny" in the -one case is sufficient to convey all the elements of the offense required in the other. If certain words can be used to convey their full legal meaning in certain cases, why not all?

Statutes which would permit this mode of charging generally are infrequent. An English statutese was given that effect in England," but the same statute in Wisconsin" and Michigan"

State v. Dowers, 45 N. H. 543 (1864).

- Bishop, New Cr. Pro. 8329 (2).

w Evington v. Pcople, 181 Ill. 408 (1899); Reg. v. Gray, 9 Cox. C. C. 417 (1864).

Dy. 261 .

* Staundf. 26 \&.

4 Bl. Comm. 305 .

u People v. Shaber, 32 Cal. 36 (I867).

"Barnhard v. State, 154 Ind. I77 (1900).

H 2 Geo. IV., c. 64, $\$ 21$ (1826).

"77 Reg. v. Goldsmith, L. R. 2 C. C. R. 74 (1873); Reg. v. Stroulger 17 Q

B. D. 327 ( 1886$)$.

Statutes, 1898,84669 .

- Compiled Laws, 1897, \$11924. 
was not so interpreted." There is, however, one case flatly im point, which upholds the constitutionality of this proposal. By a statute" the following form of indictment was made sufficient to . charge perjury; namely (omitting formal parts) that the accused at a certain time and place appeared as a witness in a case between parties named, then and there being heard before a court of competent jurisdiction, and committed the crime of perjury by testi-. fying as follows (here set out testimony) which said testimony was material to the issue then and there pending in said proceeding. The objection was taken that this form did not allege that the testimony was false, that it was given wilfully and corruptly, or that an oath was lawfully administered. But the court said:12

"The whole matter thus resolves itself into this question: Does the allegation that the party charged has committed perjury, ex vi lermini, charge all the particulars, which by law constitute that crime?

"When a party is charged with having committed perjury, in testimony, as a witness. . . . he is thereby directly charged with all that goes to make up the offense. He cannot be found guilty of the perjury charged until evidence is produced which proves him guilty of every particular embraced in the definition of perjury.

"Such an indictment gives sufficient notice to the accused of 'the nature and cause of the accusition against him' required by the constitution"

This is a clear cut decision that the name of an offense may import . all the elements of the offense."

A Massachusetts statute" provides that the names of certain offenses shall be sufficient to convey all the elements of the offense. The words are declared thereby to be words of legal art. As regards "larceny-stealing" the statute was held constitutional in Comm. v. Kelly;" and as regards "murder," in Comm. v. Snell." . The other names have not been passed upon.

\footnotetext{
Enders v. State, 20 Mich. 233 (1870).

"Maine R. S., c. 123, 85.

* State v. Corson, 59 Me. 137 (1871).

* Similar reasoning, State v. Casey, 45 Me. 435 (1858); contra, Brender v. . St ate, 12 Tex. Cr. R. 613 (1882).

M Mass. R. L., c. $218 \$ 38$.

us 184 Mass. 320 (1903); Comm. v. King, 202 Mass. 379 (1909).

" Comm. v. Snell, 189 Mass. 13 (1905).
} 
In Illinois, it has been held that a charge that the accused "did obtain from A. B. his money by means and by use of the confidence game" was good and sufficient and under it any form of swindling transaction might be proved, since by legal interpretation any such swindle was a "confidence game."

The next proposition was that the allegation that the accused violated a certain statute, or section or subsection thereof, should be a sufficient allegation that he committed the offense therein defined. For this proposition there are no common law precedents and but one statutory precedent. A statute in Rhode Island w forbade the sale of intoxicating liquors except as provided in another statute and an indictment negatived the exception thus, "Said sale and delivery not then and there being as provided in section sixty of chapter eighty-seven of the Public Statutes of said State." The court in Stale v. Walsiss stated that the exceptions had to be negatived, but that this was a sufficient negativing thereof. The exceptions formed an essential element of the offense and if one essential element may be set out by reference to a statute why not all of them?

Being without precedent the proposition must be considered entirely from a practical viewpoint. The general rule in charging statutory offenses is that it is sufficient to charge facts constituting the offense in words of the statute."

"Every indictment found by a grand jury shall be deemed sufficiently technical and correct which alleges and charges the offense in the language of the statute creating the offense, or so charges the offense that it may be understood by the jury."

There are, of course, numerous exceptions but the general rule is as above stated.

In order to test the sufficiency of an indi'ti ent for a statutory offense, or to prepare his defense as to the !- $w$, the accused, or his counsel, must always have recourse to the . atute, as found

"7 People v. Depew, 237 III. 579 (1909); contra, Rode. s. $\quad$ จ. State, 12 Tex.

Cr. R. 552 (1882),h

Aub. Laws, Cap. 378, \&1 of Apr. 13, 1883.

14 R. I. 507 (1884).

70 See Joyce on Indictments, 8371 .

$\pi$ People v. Bolen, 184 III. 338 (1900), per Philips, ] 
in the books. One is frequently struck with the diligence displayed by counsel in studying the statute and determining upon the meaning of the terms used in order to find flaws in the indictment. $\mathrm{He}$ has no difficulty in discovering the essentials of the offense as defined by the statute and whether such essentials are averred in the indictment. He always stands ready to inform the court of the contents of the statute. Would he be less diligent in informing his client?

But it will be said that there are defendants without attornies and with no access to the statute books, who could not know with what offense they are charged. Would such defendants be any worse off than they are now? They now have no opportunity to test whether the facts charged constitute a crime. The court is supposed to see to that now; could not the court see to it that they are informed of what the statute forbids?

By requesting a bill of particulars, the accused person would be able to secure all the information now found in the indictment. Such a method of allegation would not change the rules as to what must be proved before the grand jury or what must be proved to the petit jury. The only difference would be that, whereas the accused now goes to the statute to find out whether the facts charged constitute an offense, he would, if this proposal were adopted, go to the statute to find what facts were charged. The accused would not be any more hampered in the preparation of his defense than he is at present. If fairness to the accused is the real test this proposal is constitutional.

The next proposition was that it would be sufficient to charge the offense by stating merely so much of the definition of the offense as is necessary to show what offense is intended. This involves a repudiation of the alleged common law principle that the indictment, to be valid, must show that an offense has been committed; that the facts stated must not be consistent with the innocence of the accused. It also requires a different interpretation of the term "essential elements" in the rule that "the indictment must state the essential elements of the offense." Many cases can be citer in many jurisdictions which hold that this repudiation and change in interpretation would be unconstitutional. The only thing which can be done to meet these cases is to show other cases where the application of these rules in their present form would have compelled decisions contra to those actually given. 
When one attempts to determine from a study of the cases just what the rule, that the indictment must state all the essential elements of the offense, means, one is lost in a maze of hopelessly contradictory and conflicting statements. Some courts say that it means that the indictment must show against any possible inference to the contrary that the accused has committed a certain offense for which he can be punished.72 This statement is not true and never has been true. At common law no indictment stated that the accused was more than seven years of age or that he was sane at the time of the commission of the offense. These things were presumed; but the courts refused to presume other matters just as easily presumable. Take the case of alleging intent. Intent is an element of almost every offense, yet it is sufficient to allege the completed acts constituting the offense. The law presumes that everyone intends the natural and logical consequences of his acts here." Take the specific offense of larceny. Parke, B., "4 says that to establish the offense of larceny at common law there must be proved the wrongful or fraudulent taking and carrying away by the accused of the mere personal goods of another, from any place, with an intent to convert them to his (the taker's) use permarently. without color of right, and to make them his own property, without the consent of the owner. The form of indictment is that "A. B. feloniously did take, steal and carry away, one gold watch of the goods and chattels of A. B." In this indictment the word "steal" therefore charged the wrongfulness and "fraud of the taking and carrying away, the intent to deprive the owner permanently of his property, the lack of consent on the part of the owner, and the absence of color of right, (if all the essential elements are charged) the reason for inferring that "steal" meant all these elements being that one could not "steal" unless those elements were all present in the transaction. But one could not "steal" unless the thing stolen was personal property and belonged to some one other than the accuscd; none the less the courts refused to draw these further inferences."

12 Barnhart v. State, 154 Ind. 181 (1900), per Baker, J.

"Comm. v. Herscy, 2 Allen 173 (Mass., 186r).

"In Reg. v. Holloway, 2 Car. \& K. 491 (1849).

"Personal property, Reg. v. Cox, I Car. \& K. 494 (1844); ownership, Barnhart v. State, 154 Ind. I77 (I900); Emmonds v. State, 87 Ala. 12 (1888); contro, Reed v. State, 32 Tex. Cr. R. 136 (1893). 
Perhaps the rule that exceptions must be negatived, when they are essential elements of the offense, will throw some light on the subject. A man cannot commit rape of his own wife, except as principal in the second degree, nor yet can commit fornication or adultery with her. So it would seem that marriage between the prosecutrix and the accused should be negatived in these three cases. But the marriage need not be negatived in charging rape, se although in charging fornication and adultery it must." When we turn our attention to the negativing of exceptions found in statutes we get into an even more hopeless muddle. An exception in the enacting clause, or incorporated thereinto by reference must be negatived as an essential element of the offense. This is one way of stating the rule, and the courts struggle with the question-When is a reference sufficient to incorporate?" But sometimes exceptions in the enacting clause need not be negatived." Compare indictments for common law offenses and for similar statutory offenses. . An indictment under a statute making it criminal to procure the miscarriage of a pregnant woman, "unless such miscarriage is necessary to save her life," must negative the exception." But an indictment for murder need negative no excuse or justification."

This discussion of what are the essential elements of offenses is vague and indefinite, but it is no more vague and uncertain than . are the expressions of the various courts when dealing with the subject. The whole problem is "up in the air." If any case be cited as proving that such and such circumstance is an element of the offense, other cases can always be cited showing that the same or a corresponding element, though just as necessary to be proved, is not an essential element of another class of crimes.

It is impossible to find many common law precedents for the proposition that an indictment should be sufficient which contains so much of the definition of the offense as is necessary to show what offense is intended, omitting in many instances what the

70 Rex. v. Allen, 2 Moody 779 (1840).

" Comm. v. Murphy, 2 Allen 163 (Mass., I86t).

7 Joyce on Indictments, $\$ 390$, citing U. S. v. Cook, 17 Wall. 168 (U. S., 1872); State v. Norton, 45 Vt. 258 (1865); etc.

7 State v. Bush, 13 R. I. 198 (188z).

10 State v. Aiken, 109 lowa $6+3$ (1899).

"Comm. v. Hersey, 2 Allen 173 (Mass., 1861). 
courts have held to be essential elements of that offense. At common law, the usage in charging the mure ordinary offenses was to use some single word which had been held sufficient to convey many of the essential elements, such as "feloniously steal," in charging larceny, "with malice aforethought murder" in charging murder, "ravish" in charging rape. Holding that these words stated the elements, the courts were not constrained to hold that any elements might be omitted. But when statutory crimes were created, the legislatures failed to provide that certain words should similarly be words of art to convey the elements of the statutory offenses and the rule was applied that all the elements must be distinctly stated in an indictment for a statutory offense.

There can be but little doubt that it would be as fair to put an accused person on trial on an indictment which shows what offense is intended as it is to put him to trial upon the present common law indictments. His notice of the facts to be proved against him will be just as complete. The accused is now presumed to know the meaning of the words "murder," "ravish," "common barrator," and so on. It is a no more violent presumption to presume that he knows all the elements of an offense indicated. But it will be said that the grand jury must find all the elements, and without an averment of them, what assurance is there that they did hear evidence on them all? The answer to this is, that the grand jury never does find all the elements. They hear nothing in regard to those elements which lie particularly in the knowledge of the accused. They do determine that the seller of liquors had no license. They hear no evidence as to whether or not he did not have some excuse or justification which would relieve his acts of criminality.

Compare these two cases. An indictment for bigamy must negative any legal presumption of death of the former spouse if such exception be contained in the enacting clause of the statute defining the offense." But if it be found in another section of the statute, there is no necessity for negativing it.os So far as the accused was concerned the offense was exactly the same in each case, and if fairness to him required that the legal presumption of

\footnotetext{
"Hutchins v. Statc, 28 Ind. 34 (1867).

* People v. Pricstly, 118 Pac. Rep. 965 (Cal., 1911).
} 
death should be negatived in one case, it also required the negation in the other.

The constitutional right of the accused to demand the nature ard cause of the accusation against him requires that he be given fair notice that he may prepare his defense, and a discussion of the cases which hold that forms of accusation which do omit essential elements are constitutional will aid in the determination of whether this proposal is practical or not. The simplest illustration will be given first. As has been pointed out the necessity for negativing an exception, excuse or proviso depends upon how closely it is connected with the definition of the offense, which is the same thing as whether or not it is to be found in the enacting clause of the statute creating the offense or connected therewith. No exception found in a separate statute ${ }^{\text {s }}$ or in a separate or distinct clause of the same statutess need be negatived. It is therefore possible for every offense to be so defined by statute, that, although the offense is exactly the same. as at present, the indictment need not negative a single exception. The exceptions are just as essential to an understanding of the offense whether they be found in the enacting clause or in subsequent sections. Constitutionally, they need not be negatived if found distinct from the enacting clause; and, constitutionally, it should be possible to omit the negation if they be found in the enacting clause. It has been so held in a case" in which a statute, provicling that no negative allegations of any kind need be averred in any complaint under a law forbidding the sale of intoxicating liquors, was held constitutional, on the theory that since the legislature could change the burden of avcring and proving negative allegations by placing the exceptions in another portion of the same statute, it could "accomplish the same result by direct and original enactment.""

A similar principle which would permit very general charges. also exists. When an offense is prohibited in general terms in one section of the statute, and in another entirely distinct section, the acts are specified of which the offense consists, it is not necessary

\footnotetext{
"Comm. v. Shannihan, 145 Mass. 99 (1887); Stạte v. Streiter, 81 Atl. Rep. 922 (Vt., 1911).

"State v. Broeder, 90 Mo. App. 156 (1901); Mayer v. State, 64 N. J. L. 323 (1900).

"State v. Beswick, 13 R. I. 211 (1883).

${ }^{27}$ For a legislative claim of a rght to deal dircetly with averments of negative allegations, see Mass. R. L., 1902, c. 218, \$37.
} 
that anything but the general description shculd be set out in an indictment. If by changing the form of the statute creating the offense the legislature can make general charges sufficient, it can constitutionally accomplish the same result by direct enactment.

That the indictment need not, under our constitutions, directly state what is to be proved may be shown by another class of cases. The statutes defining what is commonly known as the crime of obtaining by false pretences, in some jurisdictions, call such offense larceny, and the courts have held that a commion law count for larceny may be sustained by proof of false pretences. The elements of common law larceny and of false pretences are very different, but the cases hold that "take, steal and carry away" charges larceny and larceny includes false pretences and therefore the accused is adequately forwarned." And similarly a conviction may be had in West Virginia on an indictment charging simple larceny, "not only for simple larceny but for receiving and concealing stolen goods, obtaining under false pretence, or embezzlement." This is because statute law declares these offenses larceny. It is obvious that only the elements of simple larceny are alleged by sucn indictment. In Massachusetts a statute already noted" makes a charge of "stcaling" equivalent to a charge of larceny, embezzlement and obtaining by false pretences, and this was held constitutional." The accused person is held to be fully protected from surprise by his right to demand a bill ofparticulars. 05

The most complete and universal substantiation of the proposition that any form of charge which as a matter of fact gives the accused person fair notice is constitutional is to be found in indictments which charge the most serious offense known to the law, murder in the first degree. As is generally known, the American States, almost without exception, have by statute divided the offense of common law murder into two degrees. The earliest statute to that effect and the one that may be taken as typical of all the others was passed in Pennsylvania in 1794." It reads:

* State v. Casey, 45 Me. 435 (1858).

* Anable v. Comm., 24 Grat. 563 (Va., 1873).

2 State v. Lewis, 72 S. E. Rep. 475 (W. Va., I9tI).

1 Mass, R. L., 1902, c. $218,838$.

n Comm. v. Kelly, 184 Mass. 320 (1903).

2 State v. Lewis, 72 S. E. Rep. 475 (W. Va., 1911); Comm. v. King, 202 Mass. 379 (1909).

H Act of Apr. 22, 1794, 82; Smith's Laws, Vol. II, p. 187. 
"All murder which shall be perpetrated by means of poison, or lying in wait or by any other kind of wilful deliberate and premeditated killing; or which shall be committed in the perpetration of, or attempt to perpetrate, any arson, rape, robbery, or burglary, - shall be murder in the first degree; and all other kinds of murder shall be deemed murder in the second degree."

It is obvious that no person can be convicted of murder in the first degree unless it be proved that he killed with deliberate premeditation or by one of the other methods enumerated. It is therefore certain that, under the common law rules of pleading and most definitions of essential elements, deliberate premeditation should be charged in any indictment for murder in the first degree, as an essential element of the offense. But the Pennsylvania statute above noticed, further provides:

"And the jury before whom any person indicted for murder shall be tried, shall, if they find such person guilty thereof, ascertain in their verdict whether it be murder in the first degree or second degree."

This was interpreted to mean that the common form of indictment for murder was sufficient," and constitutionally so. Some twenty-six or more states have followed this decision."

The legisla.ture of Pennsylvania later simplified the indictment for murder. Copying an English statute." it enacted that:

"In any indictment for murder it shall not be necessary to set forth the manner in which, or the means by which, the death of the deceased was caused, but it shall be sufficient in every indictment for murder to charge that the defendant did feloniously, wilfully and of his malice aforethought kill and murder the deceased."

This statute was enacted into law in ten or more other states.

The effect of this statute is to make sufficient an indictment which charges mercly the essential elements of common law murder, and it has been held that upon an indictment which charges "that A. B. did feloniously, wilfully, and of his malice aforethought kill and murder C. D.," the accused person may be convicted of

\footnotetext{
"White v. Comm., 6 Binn. 179 (Pa., 1813).

"Bishop. New Cr. Pro., Vol. II, 8584, note 6.

"I4 \& 15 Vict., c. 100,86 (1851).

- Act of Mar. 3t, 1860, \$20, P. L. 433.
} 
murder in the first degree." Bishop in his work on Criminal Procedure, 100 points out that neither the common law form of indictment nor the legislative form above set out charge the deliberate premeditation which must be proved to establish murder in the first degree. His arguments to that effect are unanswerable. These forms do not directly charge deliberate prerneditation and under the common law rules would be insufficient. His conclusion is that the legislatures had no power to prescribe these forms as sufficient, and that they are unconstitutional. In so holding he condemns as erroneous the decisions of some twenty-five or more courts, including the United States Supreme Court. ${ }^{203}$ He cites in support of his positions the decisions of some ten states, in but few of which the flat question of constitutionality was raised.

It is submitted that the more numerous decisions are correct, that the forms are constitutional. But "how can they be constitutional if they omit an essential clement of the offense?" will be asked. The only answer is that the indictment need not allege all the essential elements of the offense in order to be constitutional. The indictment which contains sufficient matter to enable the accused to prepare his defense is constitutional. This the indictment for murder does. No attorney for a person accused of murder has ever justly claimed that he did not get a fair trial because this form of indictment enabled the prosecution to surprise him. If any person had been unjustly hung, being unable to present his defense because he did not expect deliberate premeditation to be shown under the charge, the newspapers would have been full of it. Accused persons get a fair trial in Canada where the charge reads that "A murdered B" ${ }_{108}$ and a fair trial is all that the constitutions require.

Thus the courts have held that an indictment which shows that the prosecution intends to prove one of two offenses (murder in the first degree or murder in the sccond degree) or that the prosecution intends to prove one of three offenses (larceny, embezzle-

- Goerson v. Comm., 99 Pa. 388 (1882); Rowan v. State, 30 Wis. 129 (1872): Granes v. State, 45 N. J. L. 347 (1883); State v. Noakes, 70 Vt. 247 (1897); Andrews v. Pcople, 33 Colo. 193 (1905); People v. Stubenvoll, 62 Mich. 329 (1886); State v. Sheppard, 49 W. Va. $5^{82}$ (1901).

100 Vol. II, \$\$568-577.

${ }^{201}$ Danes v. Utah Ter., 151 U. S. 262 (1893).

108 \$8.52, form 64. 
ment, or false pretences) is constitutional. They should, therefore, not hesitate to hold that an indictment which shows what single offense the prosecution intends to prove is also constitutional even though such indictment omits certain elements of that offense which may fairly be inferred from what the indictment does state. 203

Thus far only the constitutionality of the proposed ways of identifying the offense have been discussed. Let us turn our attention to the constitutionality of the proposals regarding those averments which serve to individualize the transaction.

The full effect of all the proposals in regard to such avermente: is that these averments may be inserted in the charge by the prosecuting officer at any time sufficiently prior to the trials to enablethe accused to prepare his defence thereto, and that if the accused fails to ask for such particulars he will be deemed to have waived. his right thereto.

It requires no argument to demonstrate that, where the constitution of the jurisdiction does not require procedure by indictment, the complete charge may constitutionally be made upon any number of documents found by any number of the departments. of the court; the prosecuting officer may present the entire chargein one or more informations or the grard jury may present part of the charge in an indictment and the prosecuting officer present: the other part in a bill of particulars. All that is constitutionally necessary is that the accused be given the right to demand that some department or departments of the court inform him of thenature and cause of the accusation against him.104 The doubtful question is whether a formal charge found by a grand jury which shows what offense is charged, but does not individualize the. transaction constituting the offense, is an "indictment" in the sense in which it is used in those constitutions which require trial by. indictment.

100 Sce Paraiso v. U. S., 207 U. S. 369 (1907), approved in Weems v. U. S., 217 U. S. 349 (1909). Holmes, J.: "The bill of rights for the Philippines, giving the accused the right to demand the nature and cause of the accusation against. him, does not fasten forever upon those islands the inability of the seventcenth century common law to understand or accept a pleading that did not exclude. every misinterpretation capable of occurring to intelligence fired with a desire. to pervert."

194 Comm. v. Kelly, 184 Mass. 320 (1903). 
At common law indictments for certain offenses were held good and sufficient which contained absolutely no allegations to differentiate the transaction upon which the prosecution intended to rely from other transactions of the same character. Indictments for barratry, affray, being a common scold and being a common night-walker ${ }^{108}$ contained no such allegations. The averments of time and place which such indictments contained did not identify the transaction because the prosecution was never bound to prove the time and place alleged.10 Similarly, under statutes, indictments have been held good, valid and constitutional which contain no individualizing allegations. ${ }^{\circ 02}$

When prosecuted for these common law and statutory offenses the accused was usually given, on request, a bill of particulars stating the transaction to be proved; but the right to a bill was not absolute, being dependent upon the discretion of the court. If the right to a bill is absolute, as is proposed, it scems certain that the few courts which held similar indictments unconstitutional would decide differently. If, in certain offenses, no individualizing .allegations are required, why should they be required in any indictment?

If the indictment for murder be taken as an illustration, it will be noticed that in those states which have adopted the English -statute which dispenses with any allegation of the means by which the murder was committed, the indictment contains but one averment to identify the transaction, namely, the name of the person killed. Numerous cases 10 hold that this is all that is constitutionally required and no cases hold otherwise.

It may be said that since it is possible to kill a man but once, the giving of his name is an absolutely certain identification of the transaction. This would be so if every person had a different nane, but it so happens that there are many duplicated names,

${ }^{105} U t$ supra, page 563 , notes 51,52 and 53 .

208 Archbold, Cr. Pl. and Prac., 24 Ed., pp. 356, 357.

${ }^{107}$ Slave trading, Schwartz v. State, 37 Ala. 360 (1861); liquor selling, Stato v. Hodgson, 66 Vt. 134 (1893), following State v. O'Neil, 58 Vt. 140 (1885): affirmed as "due process of law" at least, in O'Neil v. Vt., 144 U. S. 323 (1891); State v. Cascy, 45 Me. 435 (1858); contro, Jones v. State, 136 Ala. 118 (1903); McLaughlin v. State, 45 Ind. 338 (1873).

${ }_{100} 14$ \& 15 Vict., c. 100, 86.

100 State v. Noakes, 70 Vt. 247 (1897); and othera, us supre p. 573, note 99. 
twenty-two "John Smiths" being listed in the current telephonedirectory for Philadelphia. Which one of many millions of persons whose names are unknown to the grand jury is meant when the grand jury charges John Doe with the murder of a "person. whose name is unknown to the grand jury?"

Therefore in this exceptional case the indictment for murder contains no allegation identifying the transaction and in the preparation of his defense the accused person is forced to rely upon information not contained in the indictment. In this case the indictment is constitutional and no great complaint has ever been made of its unfairness. Even when the name of the person killed is given, it is by statute in most of the jurisdictions permitting this short form amendable;"10 so none of these indictments contain any authoritative individualizing allegation.

Thus the courts are very lax in the rules governing indictments for the most serious offense. Could they constitutionally be as lax in charging other offenses, offenses which may be repeated time and time again, against the same person? Would an indictment which did not individualize the transaction at all when charging larceny or some kindred offense be constitutionally an indictment? The name of the person defrauded is all that is necessary when charging the obtaining of money or property by the confidence game."II In charging larceny and some other offenses the name of the owner and the allegation that "money" was stolen are sufficient, "money" meaning any currency and negotiable paper."12 Twentytwo or more other states have statutes permitting this form of charge. It has been held unconstitutional to allege that A. B. embezzled "the property" of C. D. without describing the property."12 But the accused had no absolute right to a bill of particulars in this jurisdiction and it does not follow that the decision would have been the same, had he such right.

The statutes permitting amendment of indictments cover almost all the allegations which identify the transaction in indictments for the offenses which occur most frequently. These sta-

${ }^{110}$ State v. Tolla, 72 N. J. L. 515 (1905).

"II Graham v. State, 18I Ill. 477 (1899).

112 State v. Barr, 6t N. J. L. 131 (1897); State v. Terry, 109 M10. 601 (1891).

I1" State v. Silverman, 82 Atl. Rep. 536 (N. Hamp., 1912). 
tutes have frequently been held constitutional; 116 and if a given name or description may be changed, why should there be any necessity for the insertion of any name or description in the first place, other than that which is necessary to show what offense is intended?

Objection for lack of particularity comes too late after the verdict; which would not be so if the indictment lacking such particularity were not a constitutional indictment, sufficient to give the court jurisdiction.11s The cases are not numerous enough to show whether there is any limit to the lack of particularity by verdict.

Names and descriptions which cannot be ascertained by the grand jury may be omitted, provided that they are not essential constituents of the offense, ${ }^{136}$ which means that the indictment need only show what offense is intended. Necessity will not make constitutional an indictment otherwise unconstitutional.

All these lines of precedent lead to the one conclusion, namely that the indictment which shows what offense is intended is an indictment within the constitutional sense of the term. Or following the distinction taken in Newcomb v. State," quoted with approval in State v. Schnell," an indictment need only show the "nature" of the accusation. The "cause" may be learned by the accused elsewhere, and the proposal is to inform him of the "cause" by a bill of particulars.

An objection to this proposal to permit the placing of all allegations identifying the transaction in a bill of particulars will be made on the grounds that the indictment would not show for what transaction the jury indicted the accused. The grand jury might have found cause to send him to trial for one transaction and he might be put on trial for another. The answer to this is that no indictment so identifies the transaction that by no possibility could the transactions heard by the grand jury and the petit jury be different. The more numerous the distinct allegations of

i1 Sce Bishop, New Cr. Pro., Vol. I, \$897-98.

its State v. Carter, 51 La. Ann. 442 (1899); Dunbar v. U. S., 156 U. S. 185 (1894).

IIt Lang v. State, 4 Fla. 595 (1900).

${ }^{117} 37$ Miss. 383-397 (1859).

${ }^{114} 24$ W. Va. 767 (1884). 
the indictment, the less possibility will there be of such a happening, but it always exists. Two men of the same name may have been killed; similar property may have been stolen from persons of the same name. The rules of the common law said to be so framed as to make impossible such a happening were purely arbitrary. An indictment which charged the stealing of "personal property" from John Smith was bad even though John Smith had but one chattel, and the indictment which charged the stealing of "one gold watch" from John Smith was good even though John Smith had a thousand gold watches.

The courts have sometimes said that an indictment which permits of the result that the defendant may be put on trial for transactions not heard by the grand jury would be unconstitutional,"' never secming to notice that most indictments do permit of such result. - Since time is immaterial, the grand jury may have heard evidence as to an assault committed on January $I$, and the trial jury as to an assault on February $\mathrm{r}$.

Another line of cases shows that the courts do not recognize any right of the accused to be tried for the transaction for which he has been indicted. If upon an indictment charging but one offense, the prosecuting officer starts to offer evidence tending to prove two or more transactions, each constituting the offensecharged, he will be stopped by the court and compelled to elect which transaction he will prove. And in none of the cases dealing with election do we find an intimation that the prosecution must elect to prove the transaction to which the witnesses before the grand jury swore.:10 The only persons who are prejudiced by the lack of this right to have the transaction identical are the persons who have committed numerous offenses of the same character, and for them the law does not, and should not, have much consideration.

The proposal to permit amendment of all allegations individualizing the transaction is, when applied to information, merely a statement of the common law. Informations were always amendable by the prosecuting officer who presented them.

When applied to indictments it is, as before noted, ${ }^{21}$ an exten-

119 State v. Mace, 72 Me. $\epsilon_{4}$ (1884); McLaughlin v. 'State, 45 Ind. $33^{8}$ (1873).

${ }^{190}$ See Report of Commissioners for Simplification of Criminal Pleadings, Mass., Senate Doc. No. 234 (1899).

in p. 555 
sion of the English statute ${ }^{2 z}$ now commonly adopted in the various states of the United States. This statute has frequently been held constitutional.12s The United States Supreme Court, in a case .already noted, i2 held that no indictment could be constitutionally amended. Inasmuch as there was no Federal statute permitting amendment, the court could have held on common law principles that the amendment was improper without going to the extreme of holding any amendments unconstitutional. This decision does not overweigh the numerous decisions of the state courts and in view of the more liberal attitude shown in the more recent cases it is submitted that a Federal statute permitting amendment would be held constitutional by the Supreme Court.

With this discussion, this system of criminal accusation is submitted to the consideration of those persons who are interested $\mathrm{n}$ the reform of criminal procedure. The fact that the system is in practical operation in Canada, New Zealand and India, proves that the system is workable. Precedents for the various features of the system have been found at common law and in statutes in force in different jurisdictions. The different features have been held constitutional and it is submitted that the entire system is constitutional in that it secures to the accused his right to "demand the nature and cause of the accusation against him" and all the -essential advantages of the common law procedure by indictment.

L. Pearson Scolt.

University of Pertnsylvania, June, 1013.

1214 \& is Vict., c. $100,81$.

22 State v. Tolla, 72 N. J. L. 515 (1905); People v. Johnson, 104 N. Y. 212 (1887): Rough v. Comm., 78 Pa. 495 (1875): State v. Craighead, 32 Mo. 563 (1862).

IH Ex parte Bain, 121 U. S. I (1886). 